\title{
Wild Water Buffalo Bubalus arnee in Koshi Tappu Wildlife Reserve, Nepal: status, population and conservation importance
}

\author{
Top Bahadur Khatri ${ }^{1}$, Deep Narayan Shah ${ }^{2} \&$ Nilamber Mishra ${ }^{3}$ \\ 1,2 Conservation and Sustainable Use of Wetlands in Nepal (CSUWN), Training Section Building, Second floor, Forestry Complex, \\ Babar Mahal, Kathmandu, Nepal \\ ${ }^{3}$ Department of National Parks and Wildlife Conservation, Koshi Tappu Wildlife Reserve, Paschim Kusaha, Sunsari, Nepal \\ Email: ${ }^{1}$ tbkhatri@wetlands.org.np, ${ }^{2}$ shahdeepnarayan@yahoo.com (corresponding author), ${ }^{3}$ nmishra@yahoo.com
}

Date of publication (online): 26 November 2012 Date of publication (print): 26 November 2012 ISSN 0974-7907 (online) | 0974-7893 (print)

Editor: L.A.K. Singh

\section{Manuscript details:}

Ms \# 02990

Received 06 November 2011

Final received 09 July 2012

Finally accepted 29 September 2012

Citation: Khatri, T.B., D.N. Shah \& N. Mishra (2012). Wild Water Buffalo Bubalus arnee in Koshi Tappu Wildlife Reserve, Nepal: status, population and conservation importance. Journal of Threatened Taxa 4(14): 3294-3301.

Copyright: () Top Bahadur Khatri, Deep Narayan Shah \& Nilamber Mishra 2012. Creative Commons Attribution 3.0 Unported License. JoTT allows unrestricted use of this article in any medium for non-profit purposes, reproduction and distribution by providing adequate credit to the authors and the source of publication.

Author Details: TOP BAHADUR KHATRI's research interests are in resource management, parkpeople interface, community stewardship and wetland conservation in Asia. He has been implementing various integrated conservation and development projects in and around the protected areas of Nepal for over two decades. Deep Narayan Shah's research interests are in biodiversity, community ecology, biogeography, population genetics and conservation biology. In particular, he focuses on the influence of global climate and human land-use change on animal population and communities. He has been conducting research in the Hindu Kush Himalayan region and is associated with several national and international scientific organizations.

NILAMBER MISHRA's research interests are in the ecology and conservation of the large mammals of South Asia. He has been working as Conservation Officer (Warden) in the protected areas of Nepal for over two decades.

Author Contribution: DNS conceived, designed and performed the study and wrote up the paper. TBK planned the study and NM contributed in the study design and performed field study.

Acknowledgements: See end of this article.

urn:Isid:zoobank.org:pub:263B7577-CE6944F2-9A96-13A775791AF5

\section{(1))}

OPEN ACGESS | FREE DOWNLOAD
Abstract: The Asiatic Wild Water Buffalo Bubalus arnee is an endangered species restricted to South and Southeast Asia. Nepal's only population survives in the Koshi Tappu Wildlife Reserve which is located on the floodplain of the Koshi River, a tributary of Ganga. This species is under threat due to high anthropogenic pressure ranging from habitat deterioration to hybridization with domestic buffalo. Yet, the population has grown from 63 in 1976 to 219 in 2009, despite the decline in the calf/cow ratio. The present study conducted in 2009 used the block count method. The count showed the presence of a backcrossed population of 74 in addition to the total of 219 individuals. At present, a number of conservation and livelihood interventions have been undertaken to safeguard the biodiversity, particularly the wild buffalo population in the Koshi Tappu Wildlife Reserve. The community-based sustainable management approach benefiting both conservation and livelihood of local people is necessary to ensure the long term conservation of the species.

Keywords: Bubalus arnee, Critically Endangered, Koshi flood, population census.

\section{INTRODUCTION}

The genus Bubalus was widely distributed in Europe and southern Asia in the Pleistocene age, but was later restricted to the Indian subcontinent and Southeast Asia (Mason 1974). Today, the Asiatic Wild Water Buffalo Bubalus arnee (Bubalus bubalis Groves 1981) occurs in India, Nepal, Bhutan, Myanmar, Thailand and Cambodia. They are associated with wet grasslands, swamps and densely vegetated river valleys. They have been extirpated in Pakistan, Bangladesh, Laos and Vietnam. Nepal's only population thrives in the Koshi Tappu Wildlife Reserve (KTWR) which is located on the floodplain of a snow-fed perennial river, Koshi, a tributary of Ganga. The KTWR was gazetted in 1976 to preserve the habitat for the only remaining population of Bubalus arnee here as Arna in Nepal. This species is categorized as Endangered (Hedges et al. 2008) on the IUCN Red List.

The wild water buffalo is highly endangered, with a world population considered by FAO to be certainly fewer than 4000 animals (Scherf 2000). Scherf (2000) indicated that small isolated populations may remain in the Koshi Tappu Wildlife Reserve (Nepal), Bastar and Raipur districts of Madhya Pradesh and Manas Wildlife Sanctuary/Project Tiger Reserve (India), Royal Manas National Park (Bhutan), and Huai Kha Khaeng Wildlife Sanctuary (Thailand), as these populations are believed to have been least affected by interbreeding with domestic and/or feral buffalo. Flamand et al. (2003) confirmed eight out of 10 wild buffalo samples to be of pure wild variety genetically at KTWR. The census of 
Arna in KTWR has been carried out since 1976 and till now five censuses have been conducted at four uneven intervals over a 34-year period. The most recent census was in 2004 that estimated a population of 159 wild buffalo, and a highly backcrossed, semiferal population of 49 animals (Heinen \& Kandel 2006). The global and national status of this species as documented by IUCN's Asian Wild Cattle and Buffalo Specialist Group and the American Zoo Association suggested that appropriate management is of the highest conservation priority.

The KTWR has faced Reserve-people conflicts since its establishment. The effect of human disturbance varies greatly, depending on the nature and its intensity. Therefore, realizing the above situation, the Government of Nepal in 2004, declared a surrounding area of $173.5 \mathrm{~km}^{2}$ as a buffer zone. This is one of the country's innovative strategies for participatory conservation, emphasizing a buffer zone mechanism designed to reduce the adverse impact of protected areas on the livelihoods of local communities and vice versa. The total human population of the buffer zone in 2009 was 93,323 from 16,280 households. As mandated by the Buffer Zone Management Regulations, the buffer zone is entitled to receive a $50 \%$ share of the revenue generated by the KTWR for community development activities. The money received is channeled through the user groups. These user groups are formed at the settlement level and are responsible for the planning, management and supervision of the activities implemented.

The Koshi River meanders and passes through the KTWR. The river not only shapes the physical features of the region, but also modifies the ecosystem of the area and has profound impact on the socio-economic characteristics of the local communities of the buffer zone residents. The Koshi River, which changes its course quite rapidly across years, changed its main course dramatically during the monsoon of 2008 and breached a $2 \mathrm{~km}$ stretch and entered the human settlements through Kushaha Village (Khatri et al. 2010a). This sudden shift in the course of Koshi River has had a profound effect in the physical landscape and subsequent impacts towards human settlement and their agricultural fields. Large tracts of forest near Prakashpur Village and grasslands in the eastern part of the region were totally washed away. The Koshi breach brought untold misery and loss to the lives of people, not only of Nepal but also of India. After the breach of the eastern embankment, efforts were made to revert the main channel back to its original course by employing over hundreds of heavy machines and equipments backed by a strong fleet of over 1000 personnel for a period of over one year. The Reserve had to cope with all the externalities like temporary settlements within the reserve, supply of fuel wood and fodder, excessive use of local resources by both local people as well as by the construction company that was engaged in the repair and maintenance work of the breached embankment. During the course of repair and maintenance, six male Arna were moved $5 \mathrm{~km}$ south of the barrage (in Gobargarha Village) from their habitat due to the high level of disturbance. During this period, the reserve had to bear the brunt of this natural disaster.

During the period of political instability and conflict, all the security posts were damaged and the security personnel were withdrawn and merged within the reserve headquarters, Kushaha. As a result, law enforcement became very weak due to which encroachment, illegal grazing, harvesting of resources became rampant.

The main threat to the wild buffalo is the continued mixing and mingling of the wild and the domestic stocks resulting in hybridization. In addition, as a result of the Koshi flood of 2008, there were speculations of a wide scale loss of this species. Therefore, to ascertain the status, a census was conducted jointly by the Department of National Parks and Wildlife Conservation (DNPWC) and the Conservation and Sustainable Use of Wetlands in Nepal (CSUWN). Here we report the current findings and compare it with earlier censuses. Furthermore, we have assessed the current management practices to provide future management guidance.

\section{MATERIALS AND METHODS}

\section{Study area}

KTWR $\quad\left(86^{0} 55^{\prime}-87^{0} 05^{\prime} \mathrm{E} \quad \& \quad 26^{0} 34^{\prime}-26^{0} 45^{\prime} \mathrm{N}\right)$ lies in the alluvial flood plains of the Koshi River of eastern Nepal (Fig. 1). The flood plain is a complex mosaic of lotic and lentic ecosystems, characterized by grassy marshes, oxbow lakes, swamp lakes and many depressions which retain water throughout the year. 
The KTWR has subtropical climate and its topography ranges from $75-100 \mathrm{~m}$. It covers a $175 \mathrm{~km}^{2}$ core area and a $173.5 \mathrm{~km}^{2}$ buffer zone consisting of 16 VDCs (Village Development Committees) that spread across three districts of Sunsari, Saptari and Udayapur.

The KTWR was established in 1976 and designated as the first 'Ramsar site' of Nepal in 1987 because of its extensive wetlands which accommodate wintering waterfowl of international importance. It is subject to extreme flooding from June to September. Over 80\% of the area is dominated by grasses (e.g. Typha sp., Vetivera sp., Phragmites sp., Saccharum sp., etc.) and beaches, with forests of Bombax sp., Dalbergia sp. and Acacia sp. elsewhere (Sah 1997).

\section{Methods}

The study area in general was assessed and explored to get an overview to design the strategies and methodologies for the count. Additionally, local consultations, information from the reserve staff and from past population surveys was gathered. Based on these exercises, the block count method (Skinner \& Smithers 1990) was employed. The count was carried out both by foot and with the use of elephants. The census was conducted in April-May 2009, when visibility was the highest and water discharge was at the lowest. A repeat count was done for three consecutive days.

The KTWR is rectangular in shape, where Sapta

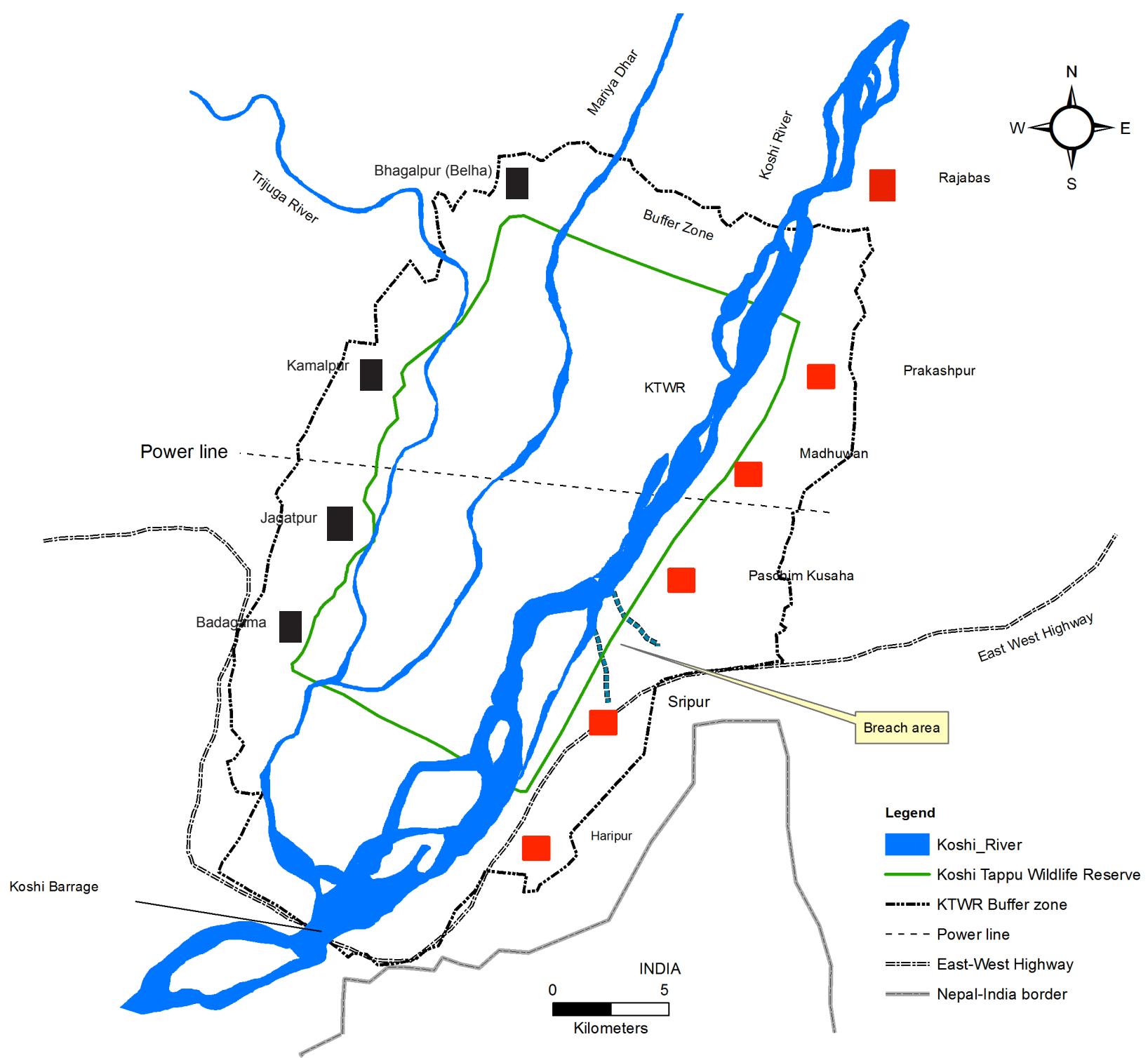

Figure 1. Study site showing Koshi Tappu Wildlife Reserve and its Buffer Zone 
Koshi, Mariya and Trijuga rivers flow from north to south. The study area was divided into four blocks, two blocks east and two blocks west of Koshi River (Fig. 1).

Block A: This block lies east of Koshi River and south of power line (Haripur/Kushaha area). The area comprises open grassland (Sacchram sp.) interspersed with a small patch of riverine forest (Dalbergia/Acacia sp.).

Block B: This block lies east of Koshi River and north of power line (Madhuwan area and Prakashpur Side Island). The major habitat of this block is riverine i.e. Khair Sisso forest, tall grassland of Sachhram sp. and Typha sp. (pater). This block has a tributary and a few constructed pilot channels.

Block C: This block lies west of Koshi River and north to power line (Pathariside Island, Bhagalpur and Kamalpur area). It has open grassland and small patches of Khair/Sisso forest. This block had heavy grazing pressure.

Block D: This block lies west of Koshi River and south of power line (Badgama/Jagatpur area). It has open grassland and small patches of Khair/Sisso forest. This block also has heavy grazing pressure. At least $1 \mathrm{~km}$ stretch along the western boundary has been encroached on for agricultural practices as well.

A complete sweep through the direct count method was employed in each block. A total of 60 surveyors were spread across different blocks with the distance kept visible to each other during the movement. Binoculars, camera and global positioning system (GPS) were used as and when required during the survey.

The wild buffalo was recognized by the behavioural and phenotypic traits such as white chevron, socks and tip of tail, and larger, relatively straight, pale-coloured horns (similar to swamp buffalo). These criteria for identifying wild buffalo from feral backcrosses were also used in earlier studies (Dahmer 1978; Heinen 1993a; Heinen \& Singh 2001; Heinen 2002; Heinen \& Kandel 2006).

The population growth rate was calculated per capita per time period by the exponential growth formula $r_{i}=\ln \left(\mathrm{N}_{\mathrm{j}} / \mathrm{N}_{\mathrm{k}}\right) \mathrm{t}($ Heinen \& Kandel 2006), where $r_{i}=$ growth rate calculated for that time interval, $\ln =$ natural logarithm, $\mathrm{N}_{\mathrm{j}}=$ population size at the end of the interval, $\mathrm{N}_{\mathrm{k}}=$ population size at the beginning of the interval, and $t=$ number of years in the interval.
Focus group discussion: In order to identify the existing threats and challenges to the existing population, a focus group discussion was conducted in addition to field observation. The group discussed different issues and their opinions towards measures to minimize local threats were documented.

\section{RESULTS}

The current study recorded a total of 219 wild water buffaloes (Table 1 and 2). Block A area comprised of a large herd of Arna with a single dominant male, its offspring including a subadult male group of seven and some isolated single males. The largest number of Arna was recorded from this block (Table 1). In Block $\mathrm{B}$, the second largest herd of Arna was recorded. A small herd of subadult males and some isolated single males were also recorded. Only small herds of Arna were present in block $\mathrm{C}$ and block $\mathrm{D}$. The population growth $\left(r_{i}\right)$ over a 34-year time period is 0.037 (Table 3). The population structure of Arna in KTWR from 1976 to 2009 (Table 2) shows that the calf to cow ratio is on a continuous decreasing trend. The ratio is a function of calve birth and survival in the first year. Therefore, the trend raises conservation concerns.

The feral and domesticated livestock were found to be in high numbers during this study, especially in block C and D (Table 4). The number of backcrossed buffalo was high in 2000 it sharply decreased in 2004 but again increased in 2009 (Table 5).

Table 1. Block wise population status of wild buffalo at KTWR

\begin{tabular}{|c|c|c|c|c|c|}
\hline Block & Male & Female & $\begin{array}{c}\text { 1st year } \\
\text { calf }\end{array}$ & $\begin{array}{c}\text { 2nd year } \\
\text { calf }\end{array}$ & Total \\
\hline A & 31 & 49 & 12 & 7 & 99 \\
\hline B & 15 & 51 & 9 & 12 & 87 \\
\hline C & 2 & 6 & 1 & 0 & 9 \\
\hline D & 7 & 13 & 1 & 3 & 24 \\
\hline Total & 55 & 119 & 23 & 22 & 219 \\
\hline
\end{tabular}


Table 2. The population structure of wild buffalo in KTWR from 1976 to 2009 , with the calf to cow ratio

\begin{tabular}{|l|c|c|c|c|c|c|l|}
\hline \multirow{2}{*}{ Year } & \multicolumn{2}{|c|}{ Adults } & \multicolumn{2}{c|}{ Calves } & \multirow{2}{*}{ Total } & \multirow{2}{*}{ Calves/cows } & \multirow{2}{*}{ Source } \\
\cline { 2 - 5 } & Male & Female & 2nd year & 1st year & & & \\
\hline 1976 & 12 & 18 & 22 & 11 & 63 & 0.61 & Dahmer (1978) \\
\hline 1987 & 32 & 29 & 14 & 16 & 91 & 0.55 & Heinen (1993b) \\
\hline 1988 & 37 & 33 & 8 & 15 & 93 & 0.45 & Heinen (1993b) \\
\hline 2000 & 56 & 53 & 17 & 19 & 145 & 0.36 & Heinen \& Singh (2001) \\
\hline 2004 & 54 & 63 & 24 & 18 & 159 & 0.29 & Heinen \& Kandel (2006) \\
\hline 2009 & 55 & 119 & 22 & 23 & 219 & 0.19 & Present study \\
\hline
\end{tabular}

Table 3. Population growth rate of water buffalo over the time period at KTWR

\begin{tabular}{|c|c|}
\hline Time interval & ri \\
\hline 1976 to $2009(\mathrm{R}$ tot$)$ & 0.037 \\
\hline 1976 to $1987(\mathrm{r} 1)$ & 0.033 \\
\hline 1987 to $1988(\mathrm{r} 2)$ & 0.022 \\
\hline 1988 to $2000(\mathrm{r} 3)$ & 0.037 \\
\hline 2000 to $2004(\mathrm{r} 4)$ & 0.023 \\
\hline 2004 to $2009(\mathrm{r} 5)$ & 0.064 \\
\hline
\end{tabular}

Table 4. The number of feral and domestic livestock inside KTWR counted in 2009

\begin{tabular}{|c|c|c|c|c|}
\hline \multirow{2}{*}{ Block } & \multicolumn{2}{|c|}{ Feral animal } & \multicolumn{2}{c|}{$\begin{array}{c}\text { Domesticated animal } \\
\text { (cattle) }\end{array}$} \\
\cline { 2 - 5 } & $\begin{array}{c}\text { Buffaloes (back } \\
\text { crossed) }\end{array}$ & Cows & Buffaloes & Cows \\
\hline A & 35 & 129 & 120 & 805 \\
\hline B & 7 & 0 & 0 & 0 \\
\hline C & 15 & 567 & 355 & 1623 \\
\hline D & 17 & 255 & 819 & 725 \\
\hline Total & 74 & 951 & 1394 & 3353 \\
\hline
\end{tabular}

Table 5. The number of backcrossed buffalo counted in KTWR. The number greatly decreased in 2004 compared to 2000 as a result of a shooting campaign. The Army began shooting buffalo of domestic origin in 2001. By March 2004, 167 buffalo had been shot inside the reserve (source: Reserve records 2005). However, this policy was controversial because some illegally grazed domestic animals were killed and the Army has since halted the culling. As a consequence, the number is gradually increasing.

\begin{tabular}{|c|c|c|c|c|l|}
\hline Year & Females & 2nd year calves & 1st year calves & Totals & Source \\
\hline 2000 & 80 & 29 & 22 & 131 & Heinen \& Singh 2001 \\
\hline 2004 & 32 & 7 & 10 & 49 & Heinen \& Kandel 2006 \\
\hline 2009 & 44 & 17 & 13 & 74 & Present study \\
\hline
\end{tabular}

\section{DISCUSSION}

The two large herds of block A and B that were recorded in this census were also recorded by the previous surveys (Heinen 1993b; Heinen \& Singh 2001; Heinen 2002; Heinen \& Kandel 2006). These herds of blocks A \& B which consist of females and calves were considered to be pure wild stock (Heinen $\&$ Kandel 2006). These herds have remained in their original form since decades; this could be due to better protection afforded through the presence of range posts and security posts in the vicinity. There is regular patrolling in these blocks. In contrast, blocks $\mathrm{C}$ and $\mathrm{D}$ have high disturbance due to grazing and other human activities. As a result, a low number of
Arna was recorded from these blocks.

The population growth $\left(r_{i}\right)$ over a 34-year time period was high overall but variable for blocks of 9-12 years. The adult sex ratio was female-biased in 1976, 2004 (Heinen \& Kandel 2006) and again in 2009, but male-biased in the three intervening censuses. Most large mammal populations have female-biased adult sex ratios (Bronson 1989; Heinen \& Kandel 2006).

The calf/cow ratio has reduced significantly over the whole time period. The calf/cow ratio reported for Arna in KTWR in all cases are consistent with the known range of natural inter birth intervals for domestic buffalo recorded in various studies and this census also shows the trend going down in calf/ cows ratio $(<2$ to $>3$ years; Cockrill 1974). Thus, the 
apparent decline in calf/cow ratio, is possibly attributed either due to the decline in birth rate or decline of the breeding populations; or increase in poaching or theft of Arna calf or death due to other reasons.

The population of feral cattle was found to be higher than the estimated population in 2000 (Heinen \& Singh 2001) which could be attributed to the lack of law enforcement/proper management. Mostly feral cattle were concentrated in blocks $\mathrm{C}$ and D, i.e., in the west of Koshi River as there was no law enforcement due to the absence of Range Posts and Security Posts. In these blocks, a large number of livestock are competing for food with Arna at the same time there is a high risk of disease transmission. Mortality from flooding, road accidents, poisoning and retaliatory killing and the transmission of diseases from domestic and feral livestock are some of the major threats for wild buffaloes. The practice of cross breeding with wild males is still a common practice.

The KTWR has had conflicts with local communities since its establishment (Heinen 1993b). The people living closer to KTWR are more likely to reveal negative attitudes towards conservation. Educated people and farmers have a positive conservation attitude to some extent while the households with poor socio-economic status and greater dependence on the KTWR for firewood, fodder and raw materials possess a more negative attitude towards conservation (Shrestha \& Alavalapati 2006). Poor households are less concerned about conservation, and institutional settings and abject poverty near protected areas appear to affect their attitudes. Therefore, for the sustainable management of KTWR and local support for natural resource conservation, socio-economic development has been initiated since the mid-1990s. The Park People Project (PPP), and Buffer Zone Policy, under implementation, has been effective in several ways (Heinen \& Mehta 2000; Budhathoki 2004; Heinen \& Kandel 2006) and many villages have benefited from the programs. This was continued by Participatory Conservation Project (PCP) and recently by CSUWN project to improve reserve-people discords by working together to realize the twin objective of conservation and development.

The political instability due to the Maoist conflict had affected conservation programmes nationwide especially since 2000 (Baral \& Heinen 2006; Heinen \& Shrestha 2006). The political instability was probably a factor in the decline of the population growth rate (Heinen \& Kandel 2006), but the recent survey showed a positive trend in the growth. The Maoist conflict created a volatile political situation (Thapa 2003) wherein the security units no longer patrolled the Reserve. Subsequently, the peace process was established in the country after a decade long political conflict, the management of the Reserve has also been improving. Recently, the KTWR management has restored a security post at Pathri, Saptari side, which has bolstered the law enforcement regime on the western side. Necessary process is underway to reinstate other security posts in other locations as well.

With the support of CSUWN project, a number of conservation and livelihood interventions have been undertaken to safeguard the biodiversity, particularly the wild buffalo population in the KTWR. The management plan of KTWR was finally approved in 2010 after a long period. This approval has entitled the buffer zone communities to receive $50 \%$ of the revenue earned by the KTWR for community development. Table 6 shows the flow of visitors and revenue earned. There is a progressive flow of tourists both locals and foreigners into the reserve area. By 2011, the Reserve has been able to earn a total of NPR 11,75,933 compared to the year 2006, where only NPR 395,891 was generated. After the approval of the management plan the revenue has shot up to NPR 671,097; double the figure earned in the year 2006. The decrease in the revenue in the year 2009 is attributed to the aftermath of the floods that occurred in September 2008, after a 2-km stretch of the Koshi River embankment was washed away by the flood resulting in the vast inundation of the eastern stretch of the reserve including human settlements and agricultural lands. The revenue generation is largely dependent on the flow of tourism therefore different protected areas have different amounts of revenue collection. The challenge exists for the protected areas that are resource poor, even though they are as important for conservation as the highly visited areas. One way to address the resource gap would be to create a basket fund in which revenue generated from resource-rich protected areas could be used to support neighbouring areas that are resource poor (Khatri 2010b). But it remains to be seen whether the stakeholders of the resource-rich protected areas would be willing to share their revenue with others in 
Table 6. Flow of visitors and revenue collection in KTWR from 2006-2011

\begin{tabular}{|c|c|c|c|c|}
\hline Year & Nepali & Foreigners & Revenue in NPR & Equivalent US\$@73 \\
\hline 2011 & 452 & 3203 & $11,75,933$ & 16108.67 \\
\hline 2010 & 438 & 1904 & 671,097 & 9193.10 \\
\hline 2009 & 159 & 145 & 224,980 & 3081.91 \\
\hline 2008 & 333 & 1594 & 591,832 & 8107.28 \\
\hline 2007 & 244 & 1271 & 424,394 & 5813.61 \\
\hline 2006 & 84 & 881 & 395,891 & 5423.16 \\
\hline
\end{tabular}

Source: KTWR

the long term.

In order to reduce crop depredation by wild animals, a solar powered electric fence has been erected in the high impact zone of the eastern sector of the KTWR. This initiative has significantly reduced the existing local discord among the local communities and the reserve management. Similarly, with the erection of the electric fence, no reports of crop depredation have been reported in that area particularly by wild buffaloes and elephants. Similarly, sustained management interventions including a community based antipoaching drive by mobilizing local youths, buffer zone communities, local teachers and eco-clubs has brought a positive impact towards the evacuation of feral cattle (cows and buffaloes) from the reserve. The reserve management with the active support of local communities has been able to collect a total of NPR 128,000 from the penalties by confiscating a total of 426 cattle (both buffaloes and cows) from the Reserve. This was the first evacuation drive ever conducted by the reserve as it is still a highly contested political issue. As a result, Table 7 shows the reduction in the number of feral and domesticated cattle recorded in the reserve. Since, no forest resources exist outside of the reserve there is a high level of grazing pressure from both feral as well as domestic stock.

A multipronged approach towards reducing the herd size of the dometic livestock by replacing it with a more productive one together with the promotion of stall feeding practice would eventually reduce the pressure on the reserve. To address the above situation, KTWR has been promoting block plantation along the western boundary of the reserve in order to create a green belt to allow local people to collect fodder for their livestock, thus discouraging illegal grazing.

With the mix of alternative options of creating a utility zone for rotational cattle grazing and fodder
Table 7. Number of feral cattle recorded in 2011

\begin{tabular}{|c|c|c|c|c|}
\hline \multirow{2}{*}{$\begin{array}{c}\text { Name of } \\
\text { block }\end{array}$} & \multicolumn{2}{|c|}{ Feral cattle } & \multicolumn{2}{c|}{$\begin{array}{c}\text { Domesticated } \\
\text { livestock (cattle) }\end{array}$} \\
\cline { 2 - 5 } & $\begin{array}{c}\text { Buffaloes } \\
\text { (backcrossed) }\end{array}$ & Cows & Buffaloes & Cows \\
\hline A & 8 & 0 & 0 & 300 \\
\hline B & 5 & 0 & 0 & 0 \\
\hline C & 5 & 105 & 195 & 1025 \\
\hline D & 0 & 355 & 215 & 305 \\
\hline Total & 18 & 455 & 410 & 1630 \\
\hline
\end{tabular}

Source: KTWR

collection backed by a strong law enforcement regime will ultimately offset the current pressure exerted on the reserve.

Under the aegis of CSUWN project, a tourism development strategy has been explored to look into the possibilities of how to develop tourism products that could benefit local people and to develop local stewardship towards conservation. Likewise, various livelihood improvement activities for wetland dependent communities such as fisheries, poultries, and wetland based green enterprise, vegetable farming, have been supported to improve the socio-economic condition of the people.

The current increase in the population doesn't provide solace, as there are a number of challenges to the long term survival of this species. A multipronged approach of conservation and development by mobilizing the buffer zone communities backed by a strong law enforcement regime would create an ideal environment to address the current management issues and concerns related to protection and conservation. The first priority should be towards enhancing conservation and harnessing the byproducts of conservation for local benefit. 


\section{REFERENCES}

Baral, N. \& J.T. Heinen (2006). The Maoist People's War and conservation in Nepal. Politics and the Life Sciences 24: $1-11$.

Bronson, F.H. (1989). Mammalian Reproductive Biology. University of Chicago Press, Chicago, USA, 325pp

Budhathoki, P. (2004). Linking communities with conservation in developing countries: buffer zone management initiatives in Nepal. Oryx 38: 334-341.

Cockrill, W.R. (1974). The Husbandry and Health of the Domestic Buffalo. FAO, Rome, Italy, 1007pp

Dahmer, T.D. (1978). Status and distribution of the Wild Asian Buffalo (Bubalus bubalis) in Nepal. MS thesis, University of Montana, Missoula, USA.

Flamand, J.R.B., D. Vankan, G.P. Ghaire, H. Duong \& J.S.F. Barker (2003). Genetic identification of Wild Asian Water Buffalo in Nepal. Animal Conservation 6: 265-270.

Groves, C.P. (1981). Systematic relationships in the Bovini (Artiodactyla, Bovidae). Zeitschrift fur Zoologische Systematik und Evolutionsforschung 19: 264-278.

Hedges, S. (1995). Asian Wild Cattle and Buffalo: Draft Status Report and Conservation Action Plan (Parts I and II). Unpublished Report, IUCN Gland, Switzerland.

Hedges, S., H.S. Baral, R.J. Timmins \& J.W. Duckworth (2008). Bubalus arnee. In: IUCN 2012. IUCN Red List of Threatened Species. Version 2012.1. <www.iucnredlist. org $>$. Downloaded on 16 October 2012.

Heinen, J.T. (1993a). Population viability and management recommendations for wild water buffalo (Bubalus bubalis) in Koshi Tappu Wildlife Reserve, Nepal. Biological Conservation 65: 29-34

Heinen, J.T. (1993b). Park-people relations in Koshi Tappu Wildlife Reserve, Nepal: a socio-economic analysis. Environmental Conservation 20: 25-34.

Heinen, J.T. \& J.N. Mehta (2000). Emerging issues in legal and procedural aspects of buffer zone management with case studies from Nepal. Journal of Environment and Development 9: 45-67.

Heinen, J.T. (2002). Phenotypic and behavioral characteristics used to identify wild buffalo from feral backcrosses in Nepal. Journal of the Bombay Natural History Society 99 173-183.

Heinen, J.T. \& R. Kandel (2006). Threats to a small population: a census and conservation recommendation recommendations for Wild Buffalo Bubalus arnee in Nepal. Oryx 40: 324-330.

Heinen, J.T. \& S.K. Shrestha (2006). Evolving policies for conservation: an historical profile of the protected area system of Nepal. Journal of Environmental Planning and Management 49: 41-58.

Heinen, J.T. \& Singh, G.R. (2001). A census and some management implications for wild buffalo in Nepal. Biological Conservation 101: 391-394.

Heinen, J.T. \& S. Srikosamatara (1996). Status and protection of Asian wild cattle and buffalo. Conservation Biology 10: 931-934.

IUCN (2010). IUCN Red List of Threatened Species. Version 2010.4, IUCN, Gland, Switzerland. <http://www. iucnredlist.org > . Downloaded on 25 May 2011.

Khatri, T.B., D.N. Shah \& N. Mishra (2010a). Post-flood status of the Endangered Ganges River Dolphin Platanista gangetica gangetica (Cetartiodactyla: Platanistidae) in the Koshi River, Nepal. Journal of Threatened Taxa 2(13): $1365-1371$.

Khatri, T.B. (2010b). Conservation governance in Nepal: protecting forest biodiversity and people's livelihoods. Unasylva 236: 61

Mason, I.L. (1974). Species types and breeds, pp. 1-47. In: Cockrill, W.R. (ed.). The Husbandry and Health of The Domestic Buffalo. Rome, Italy, Food and Agriculture Organization of the United Nations.

Read, B. (1999). Bison, Buffalo and Cattle Taxon Advisory Group. Unpublished Regional Collection Plan, American Zoo and Aquarium Association, Washington, DC, USA.

Sah, J.P. (1997). Koshi Tappu Wetlands: Nepal's Ramsar Site. IUCN Southeast Asia Regional Coordination Office, Bangkok, Thailand, 254pp

Scherf, B.D. (2000). World Watch List for Domestic Animal Diversity - 3rd Edition. Rome, Italy, Food and Agriculture Organization of the United Nations, 746pp

Skinner J.D. \& R.H.N. Smithers (1990). The Mammals of the Southern African Subregion. University of Pretoria, Pretoria, 771pp

Shrestha, R.K. \& J.R.R. Alavalapati (2006). Linking conservation and development: An analysis of local people's attitude towards Koshi Tappu Wildlife Reserve, Nepal. Environment, Development and Sustainability 8: 69-84.

Thapa, D. (2003). A Kingdom Under Siege: Nepal's Maoist Insurgency, 1996 to 2003. The Print house, Kathmandu, Nepal, 278pp

Acknowledgement: We thank the Conservation and Sustainable Use of Wetlands in Nepal (CSUWN) project, a joint undertaking of the Ministry of Forests and Soil Conservation (MFSC), Global Environmental Facility (GEF), and the United Nations Development Program (UNDP) for the financial support. We thank officers and staff, especially Ramchandra Kandel and Ashok Ram for serving as members of the technical team. We also thank CSUWN staff, KTWR staff, Raj Kumar Singh, and all other assistants who were involved in the census. 